\title{
Human Rights-Based Social Work Practice with Immigrants and Asylum Seekers in a Legal Service Organization
}

\author{
David Androff ${ }^{1}\left[\right.$ Cherra Mathis $^{1}$
}

Accepted: 28 September 2021 / Published online: 26 October 2021

(c) The Author(s), under exclusive licence to Springer Nature Switzerland AG 2021

\begin{abstract}
The human rights of immigrants and asylum seekers are threatened by the erosion of asylum and a system of crimmigration that combines immigration and criminal law. This paper explores social work practice with immigrants and asylum seekers in a legal service organization. A qualitative research study asked social workers, lawyers, and administrators $(n=27)$ to discuss the relationship between human rights and social work. Data from key informants were collected in five focus groups and one individual interview. Findings indicate that the participants see social work practice as an important response to the attack on immigrant and asylum seekers' rights. Social workers identified human rights as a primary motivation for their practice, and integral to the profession. The findings also reveal that this legal service organization applies a rights-based approach by integrating social and legal services. Participants described how this rights-based approach protects and promotes the human rights of immigrants and asylum seekers. This paper illustrates the value of rights-based approaches and how they can be incorporated into social work practice.
\end{abstract}

Keywords Rights-based approach · Social work practice $\cdot$ Immigrants and asylum seekers $\cdot$ Legal services

Immigrants and asylum seekers face unique and specific challenges seeking asylum in the USA. Increasingly xenophobic and restrictionist policies diminish their rights and threaten their well-being. Social workers are called to protect the dignity, worth, and self-determination of vulnerable populations, yet this is rarely framed in terms of their human rights (Mapp et al., 2019). Human rights offer a framework for a robust protection of people's human dignity, freedom, health, and quality of life. When the human rights of marginalized groups are violated, the rights of everyone else in society are threatened (Becerra et al., 2013). Social work practice is necessary to fulfill human rights, particularly among the most disenfranchised.

This paper examines social work practice with immigrants and asylum seekers in a legal service organization. The paper begins by detailing the human rights of immigrants and asylum seekers and reviewing the US immigration system. Next the paper situates social work practice in the context of legal service organizations, serving

David Androff

david.androff@asu.edu

1 School of Social Work, Arizona State University, 411 N. Central Ave., Ste. 800, Mail Code 3920, Phoenix, AZ 85004-0689, USA immigrants and asylum seekers, and incorporating rightsbased approaches. The methods and key findings are presented, including themes of human rights violations in the immigrant system, human rights as motivation for practice, social work's connection to human rights, and how the human rights are integrated into social work practice. The paper concludes with a discussion, implications for practice, and study limitations.

\section{The Human Rights of Immigrants and Asylum Seekers}

Human rights, such as the right to safety and security, are universal. That means they apply to everyone, everywhere, on the basis of their inherent humanity. Immigrants and asylum seekers have human rights because they are humans first and foremost.

The universality and interdependence of human rights is embodied in the 1948 Universal Declaration of Human Rights (UN, 1948). Article 13 acknowledges that freedom of movement is a fundamental human right. This entails that everyone has the freedom to choose their own place of residence, and the freedom to leave their country. Article 
14 recognizes the fundamental human right to seek asylum from persecution in other countries.

The 1951 Convention Relating to the Status of Refugees and the 1967 Protocol provide the cornerstone for the rights of people forcibly displaced (UN, 1951, 1967). The most significant is the right to nonrefoulement (Article 33). Nonrefoulement is the guarantee against being forcibly returned to the country from which someone has fled. It shields the asylum seeker from further persecution in their country of origin. In addition, the Refugee Convention affirms asylum seekers' right to freedom of movement within the country of asylum. It also identifies asylum seekers' rights to social welfare benefits and services, including housing, education, public assistance, and social security.

Other core human rights instruments further specify the rights of immigrants and asylum seekers. The International Convention on the Elimination of All Forms of Racial Discrimination states immigrants and asylum seekers have the right to nondiscrimination and equal treatment (UN, 1965). The International Covenant on Civil and Political Rights states that immigrants and asylum seekers have the right to due process and legal representation (UN, 1966). The right to be free from arbitrary arrest, detention, and exile without due process is also included in this covenant as well as the Universal Declaration. The Convention Against Torture and Other Cruel, Inhuman or Degrading Treatment or Punishment states that immigrants and asylum seekers have the right to protection from political persecution (UN, 1984). The Declaration on the Human Rights of Individuals who are not Nationals of the Country in which They Live states that immigrants and asylum seekers have the right to protection from harm such as arbitrary expulsion (UN, 1985). The International Convention on the Protection of the Rights of All Migrant Workers and Members of Their Families seeks to protect the human rights of migrant workers who often labor in dangerous conditions with precarious status; it remains unsigned and unratified by the USA (UN, 1990).

The universal human rights of asylum, protection, and nonrefoulement are international human rights law, sometimes referred to as soft law for lack of enforcement mechanisms. The primary duty-bearers of immigrant and asylum seeker rights are nation states.

However, in the last several decades, nation states around the world have diminished the right to asylum (FitzGerald, 2019). Asylum seekers increasingly are confronted with militarized borders, externalization and offshore processing, and restrictive migration policies. These measures prevent asylum seekers' ability to seek asylum, absolving states from having to grant asylum claims without technically violating their obligation to international human rights. This global trend has foreclosed legal and regular routes to safety, family reunification, and meeting basic needs. Instead, people displaced by violence, conflict, inequality, disasters, and climate change have used smugglers to escape danger and access safety, where they must traverse exceedingly perilous terrain (Androff \& Tavassoli, 2012; Mountz, 2020).

\section{US Immigration Policy}

Immigration policy in the USA has developed over 100 years of converging immigration and criminal law. This trend toward punitive and restrictive immigration policy, known as crimmigration, has accelerated in the last two decades (Ayón et al., 2012; Mathis \& Androff, 2021). Examples include using detention as deterrence and framing immigrants as "others" and threats (Kiehne \& Androff, 2020; Becerra et al., 2012).

President Bush oversaw massive securitization and militarization of the border after 9/11 (Androff, 2014). President Obama balanced providing rights and security to the children of immigrants through DACA with a record high of deportations (Hing, 2017; Johnson, 2018). Family detention and surveillance under the Obama administration morphed into President Trump's child separation policies (Barak, 2021; Eagly et al., 2018; Pittman, 2020).

President Trump further restricted the right to asylum through the Migrant Protection Protocols and Title 42. The later was initiated by the Centers for Disease Control under the Trump administration as an outsized response to the risk of COVID-19 (Hing, 2017; Human Rights Watch, 2021). It targeted asylum seekers and fed into xenophobic narratives of immigrants as vectors of disease.

People seek asylum on the basis of a credible fear of violence, that their government is unable or unwilling to keep them safe, and that they are likely to experience continued persecution if they are returned to their country of origin. Immigration judges determine whether there is enough evidence to substantiate their claim, and whether it meets the criteria (USCIS, 2021).

Immigration courts are civil courts, not criminal courts, and exist outside the main judicial system although under the executive branch. Unlike criminal courts, immigration courts provide no public defender on behalf of petitioners at risk of losing their liberty, except in cases of the most extreme physical or mental disability (Franco-Gonzalez vs Holder, 2013).

The US Constitution applies to all people within the jurisdiction of the USA, including those without legal status. However, the civil and political rights of constitutional protections are frequently not applied to asylum seekers. For example, the right against unreasonable search and seizure (Fourth Amendment) does not extend to the border, the right to due process (Fifth Amendment) is abrogated by expedited removal and streamlining procedures, and the right to legal counsel (Sixth Amendment) is avoided by the civil nature of immigration charges. 
The US government's trial attorneys generally argue against granting asylum. This is a lengthy process that requires months if not years of engagement with an adversarial court where asylum claims are most often denied (Ramji-Nogales et al., 2007). Almost 70\% of the 59,747 asylum cases decided in fiscal year 2020 lost their petitions (TRAC, 2021a, b). The consequences can be dire: detention, deportation, and the risk of death when returned to their country of origin (Human Rights Watch, 2020).

Most petitioners represent themselves, pay out of pocket, or, if they are lucky, receive pro bono advocacy. Statistically, immigrants who receive representation are much more likely to be successful in their petition (Berberich \& Siulc, 2018; Ramji-Nogales et al., 2007; TRAC, 2021a, b).

Ultimately, many detainees go unrepresented, and are forced to navigate the complexities and retraumatization of immigration court alone, with little knowledge of US immigration law and their rights and options under it (Paskey, 2016). They are required to gather necessary testimony, witnesses, and documents to substantiate both the facts and the credibility of their claims, often while being detained, or navigating other barriers such as health challenges, lack of familiarity with US systems, social isolation, and language barriers (Davis, 2014; Obinna, 2021; Paskey, 2016).

Prior to deportation, and pending their hearing, immigrants may spend months or even years in detention or under surveillance in the community due to massively backlogged courts (Koh, 2019). Data from 2019 indicate that of the approximately 51,500 immigrants held in Immigration and Custody Enforcement (ICE) detention, approximately $7 \%$ are held in private facilities run for profit, who contract with the US government, and were guaranteed a quota of filled beds (Sinha, 2016; TRAC, 2021a, b). Immigrant detention facilities, whether government run or private, have a history of lax oversight and reports of rights violations and abuse (DeLaPerriere, 2020). A new and growing alternative for migrants with "vulnerabilities not compatible with detention" is GPS monitoring and facial recognition software (Singer, 2019, p. 2), which has the benefits of physical freedom, but shackles immigrants with intrusive, privacy-violating, sometimes technologically faulty supervision that imperils them and others with precarious documentation status who are vulnerable to ICE scrutiny (Pittman, 2020).

Crimmigration does not just effect asylum seekers. Latinos in the USA experience discrimination related to restrictionist immigration policies whether they are citizens or not (Becerra et al., 2013). Latinos with lower levels of acculturation have experienced more discrimination (Becerra et al., 2015). This has led to lack of trust with law enforcement and the justice system (Becerra et al., 2017). Especially as victims of crime are unwilling to seek protection or report crime (Messing et al., 2015). Increased policing of the interior and special relationships between ICE and local police agencies can funnel immigrants into deportation proceedings for something as simple as a broken taillight (García Hernández, 2018). Even people well established who may have spent decades as contributing members of their communities are vulnerable.

\section{Legal Service Organizations}

Legal service organizations provide free or low-cost legal services to those who most need, but cannot afford, representation. They were developed to circumvent barriers to participating in the justice systems, as an outgrowth of the legal profession's commitment to justice for anyone, regardless of ability to afford counsel or their perceived "worthiness" (Houseman \& Perle, 2013). One hundred and fortyfive years since the first US legal aid society was established in New York City to support German immigrants who were too poor to pay for representation to defend their rights, legal service organizations can be found in every state in the USA (Heeren, 2011).

Legal service organizations are funded by philanthropic donations and government contracts (LSC, 2020; Udell, 2016). They depend on the generosity of individual lawyers, firms, and university legal clinics for pro bono service for staffing and expertise (Acer, 2004). Legal service organizations serve a range of disenfranchised people and communities, working in adoptions, divorce, bankruptcy, and tenant-landlord disputes, as well as immigration services.

Legal service organizations that work with immigrants assist with completing immigration forms such as asylum applications, family-based petitions, Special Immigrant Juvenile Status, T visas, U visas, Violence Against Women Act (VAWA) petitions, and other filings with USCIS. They also provide representation at asylum interviews, in immigration courts, or before the Board of Immigration Appeals (BIA) for adjustment of status, naturalization and citizenship, and removal hearings (Immigrant Advocates Network, 2021).

Access to nonprofit pro bono legal aid significantly reduces immigrant removal rates (Chand et al., 2020). Access to legal representation has been the most significant predictor of asylum petition success in immigration court, regardless of other variables (Ramji-Nogales et al., 2007). However, there is not sufficient pro bono legal representation available for every asylum seeker. To meet the demand, legal service organizations have developed legal orientation programs designed to prepare immigrants to represent themselves in immigration court. Popularized as "Know Your Rights" presentations, these programs teach the basics of self-representation.

Some legal service organizations collaborate with social work or complimentary disciplines for support in medical 
cases, housing advocacy, social services, therapeutic referrals, and a more person-centered approach that accommodates the complexity of clients both within and outside the legal case (Androff, 2016a; Chicco \& Congress, 2015). Many of these nonprofit legal service organizations also engage in state and national policy advocacy to address issues that complicate their clients' needs for protection and support (Chand et al., 2020).

\section{Social Work Practice with Immigrants and Asylum Seekers}

From its inception, the profession of social work has sought to serve immigrants and asylum seekers. Social work pioneer Eglantyne Jebb founded Save the Children in 1919 to serve children orphaned and displaced after World War I (Healy, 2008). Contemporary social work practice roles with immigrants and asylum seekers include provision of services, case management and resource brokerage, community development, and policy advocacy (Chang-Muy \& Congress, 2016; Hilado \& Lundy, 2018). Social workers assist immigrants and asylum seekers across various domains of integration such as child welfare, education, employment, and health (Dettlaff \& Fong, 2016; Potocky \& Naseh, 2019). Social workers have also addressed rising tides of nationalism and xenophobia that fuel anti-immigrant, restrictionist approaches (Popescu \& Libal, 2018).

\section{Human Rights-Based Approaches to Social Work Practice}

In addition to immigrant and asylum seeker rights, early social work pioneers also championed the human rights of children, women, and racialized minorities (Albrithen $\&$ Androff, 2014; Healy, 2008). However, in the ideological conflict of the Cold War, the USA prioritized civil and political rights over social, economic, and cultural rights. This led to an overemphasis upon laws, courts, and legal interventions as the main tools for achieving human rights. While these are important, this served to diminish the role of social workers in protecting and promoting human rights. Human rights became almost exclusively a legal profession. Mainstream social work evolved to favor individual therapeutic interventions framed from a deficit or needs-based approach. Human rights receded from contemporary social work practice.

The overly legalistic interpretation of human rights has fed the perception that human rights only exist in international documents in Geneva, as opposed to on the ground in local communities. The problem was summarized by the co-author of the Universal Declaration of Human Rights and recipient of the Nobel Peace Prize, "it would be deceiving the peoples of the world to let them think that a legal provision was all that was required ... when in fact an entire social structure had to be transformed" (Cassin, R., quoted in French, 2009).

Human rights-based approaches have been developed as a way to apply the principles of human rights into everyday practice (Androff, 2020). Originally established in the fields of public health and international development, the UN mainstreamed a rights-based approach across their programs in the late 1990s (Oberleitner, 2008). More recently, human rights-based approaches have been applied to social policy analysis (Gatenio Gabel, 2016), social investments (Androff, 2018), social work research (Maschi, 2016), community practice (Libal \& Harding, 2015), and clinical social work (Berthold, 2015).

Conceptual models for applying human rights in social work practice have also emerged. Wronka and Staub-Bernasconi (2012) developed a personal-professional practice model that integrates human rights into social workers' focus on clients, the profession, and wider society. Ife (2012) developed a threegeneration practice model that advances civil and political rights through macro practice and advocacy; social, economic, and cultural rights through micro practice for individuals and families; and collective rights through community development. This model emphasizes communities' capacity to determine and protect their own rights. McPherson (2018) developed a model for practitioners to apply human rights as a lens for assessment, as methods for intervention, and as goals for outcomes.

Another model incorporates the human rights-based principles of human dignity, nondiscrimination, participation, transparency, and accountability across social work practice domains (Androff, 2016b). In this model, social workers respect and promote the fundamental human dignity of all people. This includes recognizing all people as rights-holders, and thus fundamentally deserving, not due to a need, vulnerability, or other deficits. This principle also includes respecting peoples' self-determination and combatting the dehumanization that accompanies human rights violations. Nondiscrimination entails the prevention of discrimination on any basis, especially peoples' gender, sexual, racial, ethnic, and religious identities. This extends to national origin, language, and immigration status. Participation is both a goal and a process for rights-based social work practice that aims for empowered people to have influence and control over decisions that affect them. Transparency in rights-based social work means assessing and reporting human rights violations. Accountability entails advocacy, promoting justice and the rule of law, and raising awareness. 


\section{Methods}

This qualitative exploratory study examined social work practice with immigrants and asylum seekers at a legal service organization. The organization is situated in a large urban environment in a border state in the southwestern US. The state and city have a large, long-standing immigrant community. This nonprofit organization serves precariously documented migrants and asylum seekers in detention and throughout the court process. Their clients are predominantly but not exclusively from Mexico and the Central American Northern Triangle countries, which are Guatemala, Honduras, and El Salvador.

The research question asked social workers, lawyers, and administrators how the legal service organization's provisions of social services to immigrant and refugees were related to human rights. The research team consulted with the organization's leadership on the study design, research questions, and on snowball sampling to identify key informants. After obtaining contact information of their staff from the organization, the research team recruited participants to focus groups and interviews via email.

Twenty-seven employees agreed to participate, representing approximately one-fifth of the total organization employees, but including almost the entire social work staff. Twelve participants were social workers, nine were legal professionals (managing attorneys, staff attorneys, accredited representatives, law graduates, and legal assistants), and six were from the administrative or management team (executive director, deputy director, legal director, program manager, and human resources). Social work expertise included child, adult, and mental health focus, family separation, and program management. The participants had a range of experience with the organization, having worked there from approximately 6 months to over a decade. Although participants were not asked it, several revealed their immigration status during the focus groups. Data regarding age, gender, and ethnicity were not collected, to protect the anonymity of participants. The organization clients, asylum seekers receiving legal representation and services from the teams, were not invited to participate due to inability to protect their anonymity or confidentiality.

A university institutional review board approved the research. Participants gave informed consent prior to data collection. Participants were offered the opportunity to share their perspectives via individual interview rather than focus groups to accommodate their comfort level and schedule availability, and to minimize social and professional risks to participants. No compensation was offered.

Five focus groups were facilitated and recorded via Zoom software. Each was approximately two hours in length. The focus groups averaged five participants. The focus groups were organized by professional background and role within the legal service organization, yet all focused on the relationship between human rights and social work practice. Two focus groups were conducted with social workers, two with attorneys, and one with managers and administrators. All groups used similar prompts regarding the role of social work in the organization, its connection to human rights, and the nature of the advocacy work, for example, "How is social work related to human rights?" One individual interview was conducted with a social worker who was not available to join the focus groups.

Audio recordings were transcribed using Otter.ai software. Transcripts were de-identified; all identifying personal or professional data was removed. Transcripts were imported into Dedoose, a web-based tool for organizing, coding, and analyzing qualitative data.

The research team read transcripts for themes, identified core ideas, and came to agreement about emerging codes in the data, both deductively based on the focus group prompts and inductively, addressing higher level themes and crossquestion connections present in the responses from the three contributing groups. Child codes were applied hermeneutically and evolved and were refined through the process of application. The research team discussed coding difficulties, discrepancies, new insights, and nascent connections biweekly.

\section{Findings}

\section{The Immigration System as a Primary Frontline of Human Rights Violations}

Social workers and attorneys identified the US immigration system as violating human rights and "incredibly unjust." The victims of the system include "individuals, kids, toddlers who ... were fleeing violence." These victims, their clients, are set up to fail by the system, "so many barriers ... hinder our clients from participating meaningfully in their legal case." Participants saw violations of clients' human rights as representing a larger systemic threat, "immigration is one of the, if not the primary, frontlines on which human rights are being eroded."

Both legal professionals and social workers explained the role of legal services as responding to these human rights violations, "everything that the [organization] does is to ensure that human rights are being preserved or to regain them for certain populations." This applied to "both the legal and the social services" who each "does a lot to try to hold the line [against rights violations]."

Social workers articulated their practice in the legal service organization as protecting, restoring, and promoting 
the human rights of people caught in the system; lawyers emphasized similar observations about the contributions of their social work colleagues helping to more fully realize the substance of the rights for which the attorneys fought. The focus on human rights was described as "integral to our work." The legal staff identified the role of social work as responding to human rights violations, "social workers play a critical role in helping our clients document and address different types of abuses that they suffer in the detention centers." The social workers saw their practice as on the frontlines of the battle for human rights and responding to pressing and ongoing human rights violations.

\section{Human Rights as Motivating Social Work Practice with Immigrants and Asylum Seekers}

Social workers identified their individual commitments to human rights as motivation for their practice, "essential human rights should be a given."

I definitely believe in families being together. I do see it as human rights work at home, whether it's detention facilities, or taking on school systems that are being racist, or medical and sexual health services. I see us as supporting clients in their ability to access [and] assert their human rights.

Their passion for rights aligned with the organization's mission,

When I was seeking employment ... I didn't think it was humane for parents to be separated from their child, or their caretaker be separated from a little one, that's the reason why I seek employment [here], because someone was doing something to support them.

The social workers understood human rights as not distant and exotic, but local and relevant,

In all our [social work] classes, we've talked about human rights so much .... a lot of it was looking outside of the U.S. But especially right now, there's so much within our country that we need to focus on. I think immigration is probably one of the areas with the most egregious human rights violations right now. That's why I was really drawn to the work that's being done here.

In many cases, the social workers' understanding of human rights was informed by personal and family experiences that gave them perspective and empathy. Some of the social workers were immigrants themselves, "I'm an immigrant. I remember when our family immigrated to the U.S." They shared identity and experiences of rights violations, trauma, and the long-term consequences of these on the health and well-being of families, adults, and children, "I could relate in a way to these children coming ... I could just imagine ... the impact that can have on young children." Another social worker shared "I saw the long-term outcome of [human rights violations in the immigration system] in my Dad."

These shared experiences contributed to their motivation, "I wanted to do something that would help kids and let them know that they do have rights, and that there are people that are available to kind of help them in different parts of their life." Witnessing the impact of human rights violations on family members "motivated me to do this type of work." These experiences led them to pursue social work practice as a way to advance human rights, and specifically social work practice in a legal rights organization serving immigrants and asylum seekers.

\section{Social Work as Fundamental to Human Rights}

Participants viewed social work as directly connected to human rights work, "I feel that there isn't a separation. If you're saying that you want to go into the social work profession, then it should be a de facto that you're going to be working for the rights of everybody else." The humanization of rights-based approaches was seen as central to social work, "treating people as humans is one of the biggest concepts of social work, you know, social justice."

However, they were also conscious of the profession's ambivalence to human rights, "social work can be a part of human rights. But I don't think it is completely." When the profession upholds social workers as experts, professionals communicate a "false narrative of being some sort of heroes." They acknowledged how due to the profession's complicity in historical and contemporary oppression, social work is "clearly part of the problem, $100 \%$. It has upheld institutions, and policies that have hurt people, have gone against human rights."

The participants expressed that advancing human rights was the most impactful form of social work they could do. The social workers view their human rights-based practice as fulfilling the ethical and historical mission of the profession. It meets the promise of social work and begins to redress and overcome social work's problematic legacies and tendencies.

The findings also reveal that the participants conceive of human rights as inseparable from social work. Participants described social work as fundamentally human rights work. By treating people as fully human, the social workers emphasize their innate human value and worthiness of respect. By validating their voices and experiences, the social workers advocate for immigrant and asylum seeker rights within the immigration system. Social work practice is seen as a way to respond to human rights violations and to protect clients' rights as they navigate an oppressive 
immigration system. In this way social workers described how their practice worked to realize human rights at micro and macro levels (Androff \& McPherson, 2014).

\section{Social Work Practice as a Means for Achieving Human Rights}

The social workers identified their practice as intrinsically rights-based. They recognize that practicing social work in a legal setting was a way to protect the rights of the most vulnerable. As a legal service organization, the organization's main focus is on clients' civil and political rights. Yet the social workers expressed how civil and political rights are interdependent with social and economic rights, "our clients are so much more than their immigration case." They noted how denials of civil and political rights impacted clients' social and economic rights, "because of their immigration case, they can't meet their basic needs."

\section{Civil and Political Rights}

Social workers sought to protect the civil and political rights of their clients, known as first-generation human rights. These include the right to asylum, due process, life, safety, and self-determination, access to legal representation, and freedom from detention, persecution, and torture. By working directly with clients to succeed in their legal case and supporting the lawyers, the social workers advance civil and political rights.

In particular, participants focused on personal safety and freedom from violence as a human right, "it's just so many things about feeling safe, and being safe ... I think that's really what human rights is about, its feeling safe being who you are, and being safe being who you are." This related to clients' migration as most clients fled "disastrous situations in their home countries and hometowns," such as criminal, gender-based, or political violence. Once in the USA, abuses and deficient conditions in immigration detention disrupted their finding safety. Even when clients were released on their own recognizance or on humanitarian parole, clients' safety was challenged by trafficking, abuse, unsafe housing, and unsafe relationships.

Protection from violence was understood by social workers to be integral to the definition of human rights, "human rights is giving an opportunity for the person to feel safe, and provide a safe environment ... it is not appropriate for individuals to be detained in order to seek this safety net." To promote the right to safety, social workers ensured their clients had resources to report abuses and support for help-seeking. One legal staff explained that social workers' promoting clients' self-determination "embody what human rights are."

\section{Social and Economic Rights}

Social workers also addressed the social and economic rights of their clients, known as second-generation human rights. These include clients' rights to basic needs, food, housing, employment, and access to health care and education. The legal service model of zealous advocacy incorporates clients' social and economic rights which are obtained through social workers. An attorney explained, "there are so many needs that go beyond the delivery of legal services, [social workers] are critical in providing those services to our clients." The legal staff viewed social work practice as extending and strengthening the legal services,

If somebody's basic needs aren't being met, that includes dignity, it makes it nearly impossible to be able to focus on your legal needs ... social work is the baseline of human rights even before the legal part comes in.

The role of social workers in realizing second-generation human rights was explained by the legal staff answering prompts about the role of social workers in human rights as "access to shelter is a human right, access to health care is a human right, access to education is a human right.... the way that you get to all of those things within the [organization] are through social workers." This was accomplished through social workers helping clients to negotiate multiple systems, "every individual has a human right to learn how to properly navigate systems." The social workers provide for their clients' social and economic rights through casework, resource brokering, and direct services. These rights include the human rights to housing, education, decent work, and an adequate standard of living.

The participants described the rights-based approach as responding to the various aspects of their clients' lives. The social workers go beyond pursuing clients' rights as defined by the immigration system, to attend to the whole person. This allows for more holistic, ethical, and humane services. The holistic approach reflects the interdependency and indivisibility of human rights. The legal and social work team members focus on different but congruent rights which allows for more effective realization of rights. Their rights-based approach allows flexibility within cases and therefore the ability to address complex client needs, ultimately accommodating a spectrum of clients' rights. Rights-based social work practice requires interacting with complex individuals across multiple crosscutting systems, only one aspect of which is a legal case. A rights-based approach permits the client to be validated and their voice to be amplified in the system. 


\section{Principles of Human Rights-Based Social Work Practice}

These findings show that the social workers are applying the principles of rights-based practice in their work, including human dignity, nondiscrimination, participation, transparency, and accountability.

The social workers aim to ensure that clients have the rights to human dignity, respect, and humane living conditions regardless of their legal status. Human dignity entails the humanization of the client in a system that dehumanizes immigrants and asylum seekers. The integrated model of social and legal services approaches the client as a whole person, within a system, but having needs and rights outside of and beyond that system. While the legal team defines success in terms of the legal case, the social workers bring a more person-centered approach to establishing their human rights. Together the collaborative teams support their human dignity.

Clients' human rights are at the center of social work practice in the legal service organization. The social workers combat the dehumanizing aspects of the immigrant system that do not treat clients as whole human beings. They approach each client as a whole person, not just a legal problem, and address the whole person's needs and rights. This allowed them to address clients' needs and fulfill rights to physical health care and mental health care, including addressing trauma that was affecting their legal case. This upholds the human dignity of clients by working for their long-term success, not just their short-term legal case. The client's well-being and their rights continue beyond the courthouse.

The social workers practice nondiscrimination by working to fulfill the rights and basic needs of their clients, no matter their national origin. They respond to discrimination that their clients faced in detention, the court system, and society. The findings also confirm another facet of nondiscrimination in practice, which is reducing the power differential between practitioners and clients. The social workers accomplish this by relating to their clients as equals, and treating them as fully human, deserving of rights and dignity. Participants noted how human rights-based social work practice requires overcoming dynamics of hierarchy that perpetuate power differentials and maintain oppressive structures.

The social workers also support clients' participation. Through their rights-based approach, the social workers facilitate clients' active and meaningful involvement in their immigration case and their own lives. They achieve this by supporting clients' self-determination. They uphold transparency by representing clients' needs and rights to the court. They encourage accountability by supporting the legal service organization's legislative and political advocacy efforts. This includes providing community events that educate the public and contribute to building a human rights culture. In this way they are supporting the larger social movement for immigrant and asylum seeker rights.

\section{Limitations}

This study is limited by several factors. The qualitative research design limits the generalizability of the findings, due to purposive and snowball sampling, and use of self-report. While this is appropriate for an exploratory study, further research could apply instruments to measure various aspects of practice, such as stress, burnout, resilience, workplace support, or turnover intentions. Future studies may survey the organization's staff to learn more about the nature of their work. Another limitation is the missing voices of the asylum seekers themselves. The organization's clients were not invited to participate due to the primacy of concerns for their safety, anonymity, and freedom from retaliation. Future research should include the perspective of service-users in ways that protect their confidentiality, informed consent, and other rights as research participants.

\section{Implications}

This study shows how social work practice is an essential support for peoples' rights in the US immigration system. To fulfill the profession's potential, social work should incorporate more rights-based approaches to practice with immigrants and asylum seekers (Popescu \& Libal, 2018).

Social work practice can be strengthened with rights-based approaches. Social work practice must attend to the human rights of immigrants and asylum seekers. This includes working with lawyers and in legal service organizations to protect civil and political rights. Yet it also means providing for basic needs to meet social, economic, and cultural rights.

This study also shows how rights-based social work practice can be applied. Social workers should use more rightsbased approaches in their practice. Rights-based approaches can strengthen their practice, improve the lives and wellbeing of people and communities, and fulfill social work values. These findings can be applied to other organizations and practice contexts where social workers are embedded in advocacy teams. Rights-based approaches to social work practice can be strengthened by building on practitioner's commitment to addressing unjust systems, their motivation to promote human rights, their ethical mandates, and their skills for realizing both civil and political and social and economic rights. Integrating social work and legal advocacy 
in immigrant-rights organizations and other contexts can amplify human rights.

Social workers should partner more with legal service organizations. Social work and legal collaborations are a rich practice tradition. Given the power of law in society, these interprofessional partnerships can dramatically increase the impact of social work practice, and also may strengthen legal services. Social workers working in collaborative teams with attorneys must manage tensions that arise from power differentials and the ethical obligations of each profession. Rightsbased approaches do not erase these complications but may provide a bridge across which disciplines can meet in their pursuit of their mission of dignity, self-determination, protection, and safety for their clients.

Social work researchers should continue to examine the role and relevance of human rights to social work practice. More research is needed on social work practice with immigrants and asylum seekers. Research on interprofessional practice with lawyers is also needed. Also, more research should investigate the impact of rights-based approaches on the people that social workers serve.

Social workers must increase their advocacy for human rights on the national and international stage. Social workers can elevate the voices of survivors of the USA's immigration procedures and call for alternatives to immigration detention. Social workers should advocate for the USA to sign, ratify, and implement the international covenants and conventions, especially the International Convention on the Protection of the Rights of All Migrant Workers and Members of Their Families, that embody duty-bearers' obligations to the human rights of asylum seekers (UN, 1990). In these ways social workers can help to rebuild an immigration process that honors the right to asylum and the human rights of the forcibly displaced.

As observed by the study participants, immigrant and asylum seeker rights are being eroded. Social workers practicing in legal service organizations are fighting to protect immigrant and asylum seeker rights. Social work practice that protects the rights of immigrants and asylum seekers is necessary to resist the global retreat of asylum. Social workers have a role to play in preserving the human rights of vulnerable populations. In doing so, social workers can protect everyone's rights. This study shows how social workers are protecting human rights and doing so with rights-based approaches. In the process, they are fulfilling social work's historical mandate for the new millennium.

\section{References}

Acer, E. (2004). Making a difference: A legacy of pro bono representation. Journal of Refugee Studies, 17, 347-366. https://doi.org/10.1093/jrs/ 17.3.347
Albrithen, A., \& Androff, D. (2014). The convergence of social work and human rights: Exploring the historical and ethical foundations of allied disciplines. Indian Journal of Social Work, 75(4), 535-552.

Androff, D. (2014). Human rights and the war on immigration. In R. Furman \& A. Akerman (Eds.), Criminalization of Immigration: Contexts and Consequences (pp. 147-162). Carolina Academic Press.

Androff, D. (2016a). The human rights of unaccompanied minors in the USA from Central America. Journal of Human Rights and Social Work, 1(2), 71-77.

Androff, D. (2016b). Practicing rights: Human rights-based approaches to social work practice. Routledge.

Androff, D. (2018). Human rights-based social investments. Journal of Sociology and Social Welfare, 45(4), 169-190.

Androff, D. (2020). Rights-based framework and social work. In C. Franklin (Ed.), Encyclopedia of Social Work Online. Oxford University Press.

Androff, D., \& McPherson, J. (2014). Can human rights-based social work practice bridge the micro/macro divide? In K. Libal, L. Healy, R. Thomas, \& M. Berthold (Eds.), Advancing Human Rights in Social Work Education (pp. 23-40). Council on Social Work Education.

Androff, D., \& Tavassoli, K. (2012). Deaths in the desert: The human rights crisis on the US-Mexico border. Social Work, 57(2), $165-173$.

Ayón, C., Moya-Salas, L., Gurrola, M., \& Androff, D. (2012). Intended and unintended consequences of employer sanction laws on Latino families. Qualitative Social Work, 11(6), 587-603. https://doi.org/ 10.1177/1473325011418871

Barak, M. P. (2021). Family separation as state-corporate crime. Journal of White Collar and Corporate Crime, 2(2), 109-121. https:// doi.org/10.1177/2631309X20982299

Becerra, D., Androff, D., Ayón, C., \& Castillo, J. (2012). Fear vs. facts: Examining the economic impact of undocumented immigrants in the U.S. Journal of Sociology and Social Welfare, 39(4), 111-134.

Becerra, D., Androff, D., Cimino, A., Wagaman, M., \& Blanchard, K. (2013). The impact of perceived discrimination and immigration policies upon perceptions of quality of life among Latinos in the U.S. Race \& Social Problems, 5(1), 65-78. https://doi.org/10. 1007/s12552-012-9084-4

Becerra, D., Androff, D., Messing, J., Castillo, J., \& Cimino, A. (2015). Linguistic acculturation and perceptions of quality, access, and discrimination in health care among Latinos in the U.S. Social Work in Health Care, 54(2), 134-157. https://doi.org/10.1080/ 00981389.2014 .982267

Becerra, D., Wagaman, M. A., Androff, D., Messing, J. T., \& Castillo, J. (2017). Policing immigrants: Fear of deportation and perceptions of law enforcement and criminal justice. Journal of Social Work, 17(6), 715-731. https://doi.org/10.1177/1468017316651995

Berberich, K., \& Siulc, N. (2018). Why does representation matter? The impact of legal representation in immigration court. Fact Sheet. Vera Institute of Justice, 3. https://www.vera.org/downloads/publications/ why-does-representation-matter.pdf

Berthold, M. (2015). Human rights-based approaches to clinical social work. Springer. https://doi.org/10.1007/978-3-319-08560-9

Chand, D. E., Calderon, M. A., Hawes, D. P., \& O'Keeffe, L. (2020). Serving immigrant communities: Effectiveness of nonprofit legal aid organizations in an age of heightened enforcement. VOLUNTAS: International Journal of Voluntary and Nonprofit Organizations. https://doi.org/10.1007/s11266-020-00205-w

Chang-Muy, F., \& Congress, E. (Eds.). (2016). Social work with immigrants and refugees: Legal issues, clinical skills, and advocacy (2nd ed.). Springer Publishing Company.

Chicco, J., \& Congress, E. (2015). Legal and social work responses to the detained and deported: Interdisciplinary reflections and actions. In 
D. Kanstroom, \& M. Lykes (Eds.). The New Deportations Delirium (pp. 147-166). New York University Press. https://doi.org/10.18574/ 9781479833313-008

Davis C. (2014). Migrant mental health, law, and detention: Impacts and alternatives. In L. Simich, \& L. Andermann (Eds.). Refuge and Resilience: Promoting Resilience and Mental Health among Resettled Refugees and Forced Migrants, Vol. 7 (pp. 211-226). Springer. https://doi.org/10.1007/978-94-007-7923-5_14

DeLaPerriere, A. (2020). Contracting in the era of mandatory immigration detention notes. Public Contract Law Journal, 49(2), 351-370.

Dettlaff, A., \& Fong, R. (Eds.). (2016). Immigrant and refugee children and families: Culturally responsive practice. Columbia University Press.

Eagly, I., Shafer, S., \& Whalley, J. (2018). Detaining families: A study of asylum adjudication in family detention. California Law Review, 106(3), 785-868. https://doi.org/10.15779/Z38WH2DF26

FitzGerald, D. (2019). Refuge beyond reach: How rich democracies repel asylum seekers. Oxford University Press.

Franco-Gonzalez v. Holder, CV-10-02211 DMG (DTBx) (C.D. Cal. Apr. 23, 2013). https://casetext.com/case/franco-gonzalez-v-holder

French, P. (2009). Everyone, everywhere: Recognition of persons with disability as persons before the law. People with Disability Australia. https://pwd.org.au/wp-content/uploads/2019/05/ EveryoneEverywhere2009.docx

García Hernández, C. C. (2018). Deconstructing crimmigration symposium: Immigration law \& resistance: Ensuring a nation of immigrants. U.C. Davis Law Review, 52(1), 197-254. https://doi.org/10. 2139/ssrn.3326202

Gatenio Gabel, S. (2016). A rights-based approach to social policy analysis. Springer. https://doi.org/10.1007/978-3-319-24412-9

Healy, L. (2008). Exploring the history of social work as a human rights profession. International Social Work, 51(6), 735-748.

Heeren, G. (2011). Illegal aid: Legal assistance to immigrants in the United States. Cardozo Law Review, 33(2), 619-674.

Hilado, A., \& Lundy, M. (eds.). (2018). Models for practice with immigrants and refugees: Collaboration, cultural awareness, and integrative theory. Sage Publications.

Hing, B. O. (2017). Entering the Trump ice age: Contextualizing the new immigration enforcement regime. Texas A\&M Law Review, 5(2), 253-322. https://doi.org/10.37419/LR.V5.I2.1

Houseman, A., \& Perle, L. (2013) Securing equal justice for all: A brief history of civil legal assistance in the United States. Washington, DC: CLASP Publication 2003; rev. 2007 and 2013. http://www. clasp.org/resources-and-publications/publication-1/Securing-EqualJustice-for-All-2013-Revision.pdf

Human Rights Watch. (2020, February 5). Deported to danger: United States deportation policies expose Salvadorans to death and abuse. https://www.hrw.org/report/2020/02/05/deported-danger/unitedstates-deportation-policies-expose-salvadorans-death-and

Human Rights Watch. (2021, April 8). US Title 42 Policy to Expel Migrants at the Border. https://www.hrw.org/news/2021/04/08/qaus-title-42-policy-expel-migrants-border

Ife, J. (2012). Human rights and social work: Towards rights-based practice (3rd ed.). Cambridge University Press.

Immigrant Advocates Network. (2021). Florence Immigrant \& Refugee Rights Project (Phoenix Office)-National Immigration Legal Services Directory-Nonprofit Resource Center. https:// www.immigrationadvocates.org/nonprofit/legaldirectory/ organization.392556-Florence_Immigrant_Refugee_Rights_ Project_Phoenix_Office

Johnson, K. R. (2018). Lessons about the future of immigration law from the rise and fall of DACA Symposium: Immigration law \& resistance: Ensuring a nation of immigrants. U.C. Davis Law Review, 52(1), 343-390.
Kiehne, E., \& Androff, D. (2020). Advancing integration: The social work response to restrictionist U.S. immigration policies. Journal of Poverty, 25(2), 119-137.

Koh, J. L. (2019). Barricading the Immigration Courts. Duke Law Journal Online, 69, 48-74.

Legal Services Corporation. (2020). Legal Services Corporation would receive \$6 million spending boost in Senate Appropriations Subcommittee bill. https://www.lsc.gov/press-release/legal-servicescorporation-would-receive-6-million-spending-boost-senate

Libal, K., \& Harding, S. (2015). Human rights-based community practice in the United States. Springer. https://doi.org/10.1007/ 978-3-319-08210-3

Mapp, S., McPherson, J., Androff, D., \& Gatenio Gabel, S. (2019). Social work is a human rights profession. Social Work, 64(3), 259-269. https://doi.org/10.1093/sw/swz023

Maschi, T. (2016). Applying a human rights approach to social work research and evaluation. Springer. https://doi.org/10.1007/ 978-3-319-26036-5

Mathis, C., \& Androff, D. (2021). The crimmigratory agenda: Hitorical, economic, and political dimensions of the criminalization of immigration in the United States. Journal of Policy Practice and Research, 2(2), 105-118.

McPherson, J. (2018). Exceptional and necessary: Practicing rights-based social work in the USA. Journal of Human Rights and Social Work, 3(2), 1-10. https://doi.org/10.1007/ s41134-018-0051-x

Messing, J., Becerra, D., Ward-Lasher, A., \& Androff, D. (2015). Latina's perceptions of law enforcement: Fear of deportation, crime reporting, and trust in the system. Affilia, 30(3), 328-340. https:// doi.org/10.1177/0886109915576520

Mountz, A. (2020). The death of asylum: Hidden geographies of the enforcement regime. University of Minnesota.

Oberleitner, G. (2008). A decade of mainstreaming human rights in the UN: Achievements, failures, challenges. Netherlands Quarterly of Human Rights, 26(3), 359-390. https://doi.org/10.1177/016934410802600303

Obinna, D. N. (2021). Alone in a crowd: Indigenous migrants and language barriers in American immigration. Race and Justice. https:// doi.org/10.1177/21533687211006448

Paskey, S. (2016). Telling refugee stories: Trauma, credibility, and the adversarial adjudication of claims for asylum. Santa Clara Law Review, 56(3), 457-530. Accessed October 14, 2021 from https:// digitalcommons.law.scu.edu/lawreview/vol56/iss3/1

Pittman, J. (2020). Released into shackles: The rise of immigrant e-carceration. California Law Review, 108(2), 587-618. https:// doi.org/10.15779/Z38X05XD1T

Popescu, M., \& Libal, K. R. (2018). Social work with immigrants and refugees: Challenges, best practices, and future directions. Advances in Social Work, 18(3), i-x. https://doi.org/10.18060/22600

Potocky, M., \& Naseh, M. (2019). Best practices for social work with refugees and immigrants (2nd ed.). Columbia University Press.

Ramji-Nogales, J., Schoenholtz, A. I., \& Schrag, P. G. (2007). Refugee roulette: Disparities in asylum adjudication feature. Stanford Law Review, 60(2), 295-412.

Singer, A. (2019). Immigration: Alternatives to Detention (ATD) Programs. Congressional Research Service. https:// www.everycrsre port.com/files/20190708_R45804_ a4bc52837d9b7b549de0428e186e0c2013ad6447.pdf

Sinha, A. (2016). Arbitrary detention: The immigration detention bed quota. Duke Journal of Constitutional Law \& Public Policy, 12(2), $77-122$.

Transactional Records Access Clearinghouse (TRAC). (2021a). Immigration court backlog tool: Pending cases and length of wait in immigration courts. https://trac.syr.edu/phptools/immigration/court_ backlog/ 
Transactional Records Access Clearinghouse (TRAC). (2021b). Asylum denial rates continue to climb. https://trac.syr.edu/ immigration/reports/630/

Udell, D. (2016). The civil legal aid movement: 15 initiatives that are increasing access to justice in the United States. Impact Center for Public Interest Law. Book 10. http://digitalcommons.nyls.edu/ impact_center/10

United Nations (UN). (1990). International Convention on the Protection of the Rights of All Migrant Workers and Members of Their Families. United Nations General Assembly. https://treaties.un. org/doc/Treaties/1990/12/19901218\%2008-12\%20AM/Ch_IV_ 13p.pdf

United Nations (UN). (1985). Declaration on the Human Rights of Individuals who are not Nationals of the Country in which they live. United Nations General Assembly. https://www.un. org/en/genocideprevention/documents/atrocity-crimes/Doc. 26_Declaration\%20on\%20the\%20Human\%20Rights\%20of\% 20Individuals $\% 20$ who\%20are $\% 20$ not $\% 20$ nationals.pdf

United Nations (UN). (1984). Convention Against Torture and Other Cruel, Inhuman, or Degrading Treatment or Punishment. United Nations General Assembly. https://legal.un.org/avl/pdf/ ha/catcidtp/catcidtp_e.pdf

United Nations (UN). (1967). Protocol Relating to the Status of Refugees. United Nations General Assembly. https://www.unhcr.org/ en-us/protection/basic/3b66c2aa10/convention-protocol-relatingstatus-refugees.html
United Nations (UN). (1966). International Covenant on Civil and Political Rights. United Nations General Assembly. https://www. ohchr.org/en/professionalinterest/pages/ccpr.aspx

United Nations (UN). (1965). International Convention on the Elimination of All Forms of Racial Discrimination. United Nations General Assembly. https://legal.un.org/avl/pdf/ha/cerd/cerd_e.pdf

United Nations (UN). (1951). Convention Relating to the Status of Refugees. United Nations General Assembly. https://www.unhcr. org/en-us/3b66c2aa10

United Nations (UN). (1948). Universal Declaration of Human Rights. United Nations General Assembly. https://www.un.org/sites/un2. un.org/files/udhr.pdf

U.S. Citizen and Immigration Services. (2021, April 2). Asylum । USCIS. https://www.uscis.gov/humanitarian/refugees-and-asylum/asylum

Wronka, J., \& Staub-Bernasconi, S. (2012). Human rights. In K. Lyons, T. Hokenstad, M. Pawar, N. Huegler, \& N. Hall (Eds.), The Sage handbook of international social work (pp. 70-84). SAGE.

Publisher's Note Springer Nature remains neutral with regard to jurisdictional claims in published maps and institutional affiliations. 